\title{
Fatal Lactic Acidosis in a Newborn Attributable to a Congenital Defect of Pyruvate Dehydrogenase
}

\author{
JOHAN H. STRÖMME, (49) OLAV BORUD, AND PETER J. MOE \\ Department of Clinical Chemistry and Department of Pediatrics, University of Tromsö, Tromsö, Norway
}

\begin{abstract}
Extract
An infant suffering from metabolic acidosis attributable to hyperlactatemia $(6.1 \mathrm{mmol} / \mathrm{liter})$ accompanied by hyperalaninemia ( $1 \mathrm{mmol} /$ liter) and hyperserinemia $(0.6 \mathrm{mmol} / \mathrm{liter})$ is described. The urinary excretion of lactate and pyruvate was greatly elevated; the lactate to pyruvate ratio was normal. The urine showed low levels of citrate, isocitrate, and cis-aconitate, and low or normal levels of $\alpha$-oxoglutarate, succinate, malate, and methylmalonate. Aspartate was slightly elevated in serum and urine, indicating a corresponding increase of its $\alpha$-ketoacid oxaloacetate. These patterns of organic acids and amino acids suggested an in vivo defect in the oxidation of pyruvate. Fibroblasts cultured from skin biopsy from the patient metabolized radioactive pyruvate (final concentration 0.04-2 mmol/liter) to $\mathrm{CO}_{2}$ at rates from 5 to $17 \%$ of that of fibroblasts from normal control subjects. Enzyme studies with fibroblast sonicates revealed a severe deficiency of the pyruvate dehydrogenase complex (about $8 \%$ of normal), and this error was localized to the first unit of the complex, i.e., the pyruvate dehydrogenase (about 4\% of normal). Fibroblasts from both parents metabolized pyruvate to $\mathrm{CO}_{2}$ at a slightly reduced rate, suggesting parental heterozygosity.
\end{abstract}

\section{Speculation}

An exact classification, which may have both prognostic and therapeutic implications, of patients suffering from the heterogenous group of diseases, congenital lactic acidosis, will be possible only when the various underlying defects have been demonstrated. Since we are probably dealing with errors localized close to the center of the energy metabolism, sophisticated in vivo and in vitro studies will be required to reach this goal. However, we expect each defect to give rise to secondary derangements in the patterns of organic acids and amino acids in serum and urine, which are more or less typical for each defect. Once these patterns are known, a precise biochemical diagnosis may be reached by comparatively simple examinations.

Increased blood levels of lactate in humans are most frequently secondary to acquired diseases (25). Some 30 patients with primary lactic acidosis have been described in the literature since 1962 (12,15,31). These patients represent a heterogenous group of genetically determined inborn errors (33). The first symptoms are most often noted in the first 2 years of life, but may appear as late as $10-20$ years of age. The course may be transient, fatal in the neonatal period, or progress more slowly to become fatal later in life (31).

The exact metabolic defect has not been established in the majority of the patients reported $(31,34)$. However, in the last few years, at least four different enzyme deficiencies have been shown to be present in patients with congenital lactic acidosis. A deficiency of the first unit of the pyruvate dehydrogenase complex (pyruvate dehydrogenase, previously often called pyruvate decarboxylase EC. 4.1.1.1) has been found in four patients $(4,6,12)$, and a defect in the second unit (dihydrolipoyl transacetylase, EC. 2.3.1.2) or in the third unit (dihydrolipoyl dehydrogenase, EC. 1.6.4.3) in one patient (7). Error in pyruvate carboxylase has been demonstrated in several patients, most of them classified as Leigh's subacute necrotizing encephalomyelopathy $(14,19,37)$. A defect in fructose-1,6-diphosphatase has been demonstrated in three patients $(3,5,26)$. In addition, glucose-6-phosphatase deficiency (glycogen storage disease, type 1) may be accompanied by lactic acidosis.

The present report concerns an infant who developed hyperlactatemia hyperalaninemia, lactaturia, and pyruvaturia during the first days of life. The child died at three weeks of age. Metabolic and enzyme studies on skin fibroblasts revealed a defect in the oxidation of pyruvate localized to the pyruvate dehydrogenase $(40)$

\section{CASE REPORT}

$L S$, a female infant born on October 9, 1973, was the first child of a 20-year-old Norwegian female, who had previously had an abortion in the third gestation month. The family history was noncontributory. The mother had been treated with anticonvulsive drugs since the age of 11 and had received Zaronthine, $0.5 \mathrm{~g}$, and phenobarbital, $75 \mathrm{mg}$, daily during pregnancy. The pregnancy was otherwise uneventful. The delivery occurred at term without difficulties; birth weight was $2,600 \mathrm{~g}$. At delivery, the infant was flaccid, cyanotic, and apneic. Artificial respiration was given, and she received $5 \mathrm{ml}$ isotonic bicarbonate in the umbilical vein. Her condition improved, and she was later transferred to the Department of Pediatrics, The University of Tromsö.

\section{STATUS ON ADMISSION}

On admission at age $12 \mathrm{hr}$ she had a marked generalized edema without pitting, particularly on the dorsal surface of the hands and feet, and slight generalized petechial eruptions. Respiration seemed normal but she was slightly cyanotic, particularly on the hands and feet. The head was normocephalic and the mandible small. Her cry was weak. There was bilaterally reduced abduction in the hip joints and positive Ortolani's sign. The feet were misshaped with runner-form.

\section{LABORATORY FINDINGS}

On admission, hemoglobin was $163 \mathrm{~g} /$ liter, white blood cell count $16,600 / \mu \mathrm{l}$, and thrombocytes $438,000 / \mu \mathrm{l}$. Coombs test was negative. Coagulation studies were normal. Dye test for toxoplasmosis was negative. At $12 \mathrm{hr}$ of age the arterial blood $\mathrm{pH}$ was $7.23, \mathrm{pCO}_{2} 51 \mathrm{~mm} \mathrm{Hg}$, standard bicarbonate $17 \mathrm{mmol} / \mathrm{liter}$, and base excess $-8 \mathrm{mmol} /$ liter. Oxygen saturation was normal. The serum electrolytes were sodium $129 \mathrm{mmol} /$ liter, potassium 4.5 $\mathrm{mmol} /$ liter, chloride $97 \mathrm{mmol} /$ liter, and calcium $2.1-2.8 \mathrm{mmol} /$ liter. Blood glucose was $76 \mathrm{mg} / 100 \mathrm{ml}$, and total serum protein 46 $\mathrm{g} /$ liter with normal electrophoresis. Routine urinalysis was normal, urine $\mathrm{pH}$ was 6 , and tests for ketones were intermittently 
slightly positive. The alanine aminotransferase (GPT) and aspartate aminotransferase (GOT) in serum were normal. Lactate dehydrogenase $(\mathrm{LDH})$ was $1,100 \mathrm{U} /$ liter (normal $<700 \mathrm{U} /$ liter), but the isoenzyme pattern was normal $\left(\mathrm{LDH}_{1} 38 \%, \mathrm{LDH}_{2} 48 \%\right.$, $\mathrm{LDH}_{3} 11 \%, \mathrm{LDH}_{4} 2 \%$, and $\mathrm{LDH}_{5} 1 \%$ ).

Serum and urine levels of organic acids and amino acids of particular interest are listed in Table 1. The lactate to pyruvate ratio in urine was 7 , which is normal. The following amino acids were present in normal amounts in serum and urine: valine, methionine, isoleucine, leucine, phenylalanine, tyrosine, lysine, histidine, and arginine.

\section{CLINICAL COURSE}

The clinical course was complicated by diarrhea which occurred on the two occasions when processed cow milk formula feedings were attempted. Later on she reacted with diarrhea even on oral sugar and electrolyte solutions. Her general condition gradually deteriorated. She developed a marked combined metabolic and respiratory acidosis. Because of the respiratory failure she had to be treated temporarily in a respirator. Terminally, she developed lung infiltrations, irregular respiration, and convulsions. She died at age 3 weeks.

\section{PATHOLOGIC FINDINGS (40)}

Autopsy revealed marked communicating hydrocephalus with grossly reduced gray and white substance, possibly caused by local but extensive destruction of brain tissue. The macroscopic and microscopic changes did not resemble the picture described in Leigh's subacute necrotizing encephalomyelopathy. Purkinje cells were present in normal amount, compatible with a destruction of brain tissue which was not caused by general anoxia. Furthermore, there was a diffuse interstitial pulmonary fibrosis.

\section{MATERIALS AND METHODS}

[1- $\left.{ }^{14} \mathrm{C}\right]-$ and $\left[\mathrm{U}-{ }^{14} \mathrm{C}\right]$ Pyruvate (sodium salts), specific activity $9-11 \mathrm{mCi} / \mathrm{mmol}$, and $\left[1-{ }^{14} \mathrm{C}\right]$ acetate (sodium salt), specific activity $58 \mathrm{mCi} / \mathrm{mmol}$, were purchased from The Radiochemical Centre (4i). Minimum Essential Medium with Hank's salts (MEM) and fetal calf serum were obtained from Gibco (42). Lactate dehydrogenase (from pig heart, no. 15372) was obtained from Boehringer/Mannheim (43), phosphotransacetylase (no. P-4383) from Sigma Chemical Co. (44). All other chemicals used were of highest available purity.

Lactic acid and pyruvic acid were determined enzymatically, using Boehringer's reagents (nos. 15972 and 15973). Amino acid chromatography was performed after deproteinization with sulfosalicylic acid by the method of Spackman et al. (36), using a Jeol amino acid analyzer, model JLC-6. Semiquantitative estimation of organic acids in urine and in deproteinized fibroblast sonicates was performed after acidic ether extraction by two-dimensional paper chromatography (first run: ethanol-ammonia-water (16:1:3, by volume), second run: $n$-butanol-acetic acid-water (13:3:5, by volume) (24). The organic acids were visualized by spraying with p-dimethyl aminobenzaldehyde or aniline-xylose reagent (24), or by autoradiography. All other clinical chemical analyses were performed with conventional methods with daily control of standards and quality control sera.

Primary cultures of human fibroblasts were obtained from skin biopsies. The cells were grown at $37^{\circ}$ in MEM with Hank's salts and with $15 \%$ fetal calf serum in Falcon plastic flasks (30 or 250 $\mathrm{ml})$. Subcultures were made every $6-9$ days by trypsination $(0.50 \%$ trypsin in MEM),

The metabolism of ${ }^{14} \mathrm{C}$-labeled pyruvate to ${ }^{14} \mathrm{CO}_{2}$ by the intact fibroblasts was assayed at $37^{\circ}$ in the culture flasks $(30 \mathrm{ml}) 5-8$ days after the last trypsination, i.e., approximately at steady state of the cells. The detailed incubation conditions are given in the legends to the figures. The incubations were ended by the addition of 0.1 mmol carrier $\mathrm{NaHCO}_{3}$ imniediately followed by $0.3 \mathrm{mmol}$ acetic acid, which decreased the $\mathrm{pH}$ to about 4 . During the following $4 \mathrm{hr}$, the ${ }^{14} \mathrm{CO}_{2}$ liberated was quantitatively trapped into a counting vial containing $0.3 \mathrm{ml}$ Soluene-350 (Packard), and the radioactivity measured about $24 \mathrm{hr}$ after the addition of $10 \mathrm{ml}$ scintillation liquid (45). The cells were subsequently washed with saline and dissolved in $0.1 \mathrm{~mol} /$ liter $\mathrm{NaOH}$ for protein determination (23).

The intracellular content of radioactive organic acids was assayed after $2 \mathrm{hr}$ of incubation of the fibroblasts $(1.2 \mathrm{mg}$ protein/ flask of $250 \mathrm{ml}$ ) at $37^{\circ}$ in $5 \mathrm{ml}$ Hank's balanced salt solution containing $200 \mu \mathrm{mol} /$ liter $\left[1-{ }^{14} \mathrm{C}\right]$ acetate (about $5 \mu \mathrm{Ci}$ ). The cells were harvested after the addition of trypsin to a final concentration of $0.25 \%$, centrifuged, and the pellets sonicated in a small volume of $2 \mathrm{~mol} /$ liter formic acid. After deproteinization, organic acids were extracted from the supernatant and subjected to a twodimensional paper chromatography as described above.

Cell-free fibroblasts preparations for enzyme assays were made by disrupting suspended washed cells, kept in ice-water bath, using a MSE $150-\mathrm{W}$ ultrasonifier. Three $10-\mu \mathrm{m}$ bursts of $10 \mathrm{sec}$, each separated by a 40 -sec cooling period, were used.

Citrate synthase was assayed essentially by the method of Wright and Sanwal (39). The cells were sonicated in $118 \mathrm{mmol} /$ liter Tris, $\mathrm{pH} 7.6$, with $100 \mathrm{mmol} /$ liter $\mathrm{KCl}$. The complete assay system contained, in a volume of $650 \mu \mathrm{l}$ in the cuvette: $100 \mathrm{mmol} /$ liter Tris, $\mathrm{pH} 7.6,100 \mathrm{mmol} /$ liter $\mathrm{KCl}, 0.2 \mathrm{mmol} /$ liter acetyl-CoA, $0.025 \mathrm{mmol} /$ liter 5,5-[dithiobis(2-nitrobenzoic acid)], $0.2 \mathrm{mmol} /$ liter oxaloacetate, and the enzyme preparation (about $15 \mu \mathrm{g}$

Table 1. Organic acids and amino acids in serum and urine ${ }^{1}$

\begin{tabular}{lcc}
\hline \multicolumn{1}{c}{ Compound } & Serum, $\mu$ mol/liter & Urine, mmol/g creatinine \\
\hline Lactate & $6,100(1,300-1,700(35))$ & $450(2.5(32))$ \\
Pyruvate & & $65(0.4(32))$ \\
Citrate & & $<.5(1-3(32))$ \\
Isocitrate & & Decreased \\
Cis-aconitate & & Decreased \\
2-Hydroxybutyrate & Slightly increased \\
Alanine & $1,439,673(292 \pm 53(9))$ & $10.79,5.37,5.50(0.27 \pm 0.13(20))$ \\
Serine & $462,679(131 \pm 27(9))$ & $4.31,3.65,3.91(0.47 \pm 0.12(20))$ \\
Glycine & $357,200(213 \pm 35(9))$ & $13.62,6.03,9.67(1.27 \pm 0.43(20))$ \\
Threonine & $175,139(177 \pm 36(9))$ & $1.03,2.74,0.98(0.11 \pm 0.04(13))$ \\
Cysteine & $38,28(42 \pm 9(9))$ & $0.69,0.41,0.45(0.15 \pm 1.15(28))$ \\
Aspartate & $62,137(19 \pm 2(9))$ & $0.15(0.05 \pm 0.04(13))$ \\
Glutamate & & 0.09, \\
Glutamine & $411,110(639(2))$ & $0.05,0.03,0.15(0.2-4.0(1))$ \\
\hline
\end{tabular}

\footnotetext{
${ }^{1}$ Normal values with references are given in parentheses.
} 
protein). The reaction, which was started by the addition of oxaloacetate after a 3 -min period of preincubation, was continuously monitored at $25^{\circ}$ and $412 \mathrm{~nm}$ for the first minutes (linear part of the curve).

The complete pyruvate dehydrogenase complex was assayed at $37^{\circ}$ essentially as described by Cremer and Teal (10). The

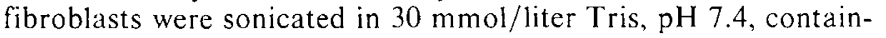
ing $100 \mathrm{mmol} /$ liter sucrose and $5 \mathrm{mmol} /$ liter $\mathrm{MgCl}_{2}$. The complete assay system contained, in a volume of $757 \mu \mathrm{l}$ in sealed flasks, the following: $50 \mathrm{mmol} /$ liter potassium phosphate, $\mathrm{pH} 7.4,2 \mathrm{mmol} /$ liter $\mathrm{MgCl}_{2}, 16 \mathrm{mmol} /$ liter nicotinamide, $1.0 \mathrm{mmol} /$ liter $\mathrm{Na}_{2} \mathrm{SO}_{3}$, $9 \mathrm{mmol} /$ liter dithiothreitol, $2 \mathrm{mmol} /$ liter thiamine pyrophosphate, $6 \mathrm{mmol} /$ liter NAD, $0.1 \mathrm{mmol} /$ liter CoA, $0.2 \mathrm{mmol} /$ liter [1${ }^{14} \mathrm{C}$ pyruvate $(0.1 \mu \mathrm{Ci} / 757 \mu \mathrm{l}), 2 \mu \mathrm{l}(5 \mu \mathrm{g}$ protein) phosphotransacetylase, $5 \mu \mathrm{l}(50 \mu \mathrm{g}$ protein) lactate dehydrogenase, and $150 \mu \mathrm{l}$ fibroblast sonicate (about $60 \mu \mathrm{g}$ protein). The reaction was started by the addition of pyruvate after a 3-min preincubation period. The incubation period was routinely $15 \mathrm{~min}$, and the reaction was stopped by the addition of $20 \mu \mathrm{mol}$ of bicarbonate immediately followed by $200 \mu \mathrm{mol}$ of acetic acid, bringing the $\mathrm{pH}$ down to about 4 . The ${ }^{14} \mathrm{CO}_{2}$ liberated was quantitatively collected on a piece of filter paper containing $100 \mu \mathrm{l} 10 \% \mathrm{KOH}$ and counted as described above. Less than $1 \%$ of the pyruvate was decarboxylated during the reaction.

The pyruvate dehydrogenase (the first unit of the complete complex) was assayed at $37^{\circ}$ in a manner similar to that described for the complete complex, according to the method described by Reed and Willms (29). The complete reaction mixture contained, in a final volume of $750 \mu \mathrm{l}$ in sealed flasks, the following: 100 $\mathrm{mmol} /$ liter potassium phosphate, $\mathrm{pH} 6.0,6.0 \mathrm{mmol} /$ liter $\mathrm{MgCl}_{2}, 2$ $\mathrm{mmol} /$ liter thiamine pyrophosphate, $18 \mathrm{mmol} / \mathrm{liter}$ potassium ferricyanide, $0.2 \mathrm{mmol} /$ liter $\left[1-{ }^{14} \mathrm{C}\right]$ pyruvate (about $0.1 \mu \mathrm{Ci} / 570$ $\mu \mathrm{l})$, and $150 \mu \mathrm{l}$ fibroblast sonicate (about $60 \mu \mathrm{g}$ protein). The incubation period was routinely $30 \mathrm{~min}$, and the reaction was stopped as described for the complete complex. Less than $1 \%$ of the pyruvate was decarboxylated.

\section{RESULTS}

The results in Table 1 suggest the presence of a defect in the utilization of pyruvate. In cultured fibroblasts from normal controls the amount of ${ }^{14} \mathrm{CO}_{2}$ formed from $\left[U-{ }^{14} \mathrm{C}\right]$ pyruvate increased in an approximately linear fashion with time (Fig. 1). The rate was significantly less in fibroblasts from the patient than in those from three normal control subjects, being about $5 \%, 15 \%$, and $17 \%$ of that of the control subjects with a final pyruvate concentration of 40,200 , and $2,000 \mu \mathrm{mol} /$ liter respectively. The amount of $1-{ }^{14} \mathrm{C}$-labeled pyruvate metabolized to ${ }^{14} \mathrm{CO}_{2}$ was approximately the same as with uniformly labeled pyruvate (8). Thus the experiments were mainly assaying the first decarboxylation step. The viability of the cells was good as judged from parallel experiments with glucose as substrate, which showed an even slightly increased rate of lactate formation in the fibroblasts from the patient (8).

The decreased rate of metabolism of ${ }^{14} \mathrm{C}$-labeled pyruvate to $\mathrm{CO}_{2}$ was not corrected by the addition of cold succinate, malate, or aspartate as sparkers of the citric acid cycle (8). Based on these observations it appeared unlikely that the defect was localized to the pyruvate carboxylase, which has recently been found in fibroblasts (18). Most likely, the error was to be found in the pyruvate dehydrogenase complex, or some place in the citric acid cycle. Two-dimensional paper chromatography of sonicated fibroblasts from the patient that had been incubated for $2 \mathrm{hr}$ with $\left[1{ }^{14} \mathrm{C}\right]$ acetate revealed low intracellular levels of radioactive intermediates of the citric cycle, notably citrate, as compared with the levels found in fibroblasts from the normal control subjects. This finding, which is in accordance with the pattern found for organic acids in urine (Table 1), suggested that the defect was localized above the citrate level of the citric acid cycle. On this basis the citrate synthase and the pyruvate dehydrogenase complex was assayed.
The activity of citrate synthase in fibroblasts from the patient appeared normal as judged from the activity measured simultaneously in fibroblasts from three normal control subjects (Table 2). The pyruvate dehydrogenase complex, on the other hand, showed an activity of only $8 \%$ of normal (Table 2). Moreover, in the presence of ferricyanide as electron acceptor, which excludes dihydrolipoyl transacetylase and dihydrolipoyl dehydrogenase of the complex from being assayed (7), a similarly low activity was found in the fibroblasts from the patient, i.e., less than $5 \%$ of normal (Table 2). Thus, a severe defect seems to be localized to the first unit of the complex (pyruvate dehydrogenase) or to the activating phosphatase of the dehydrogenase. The latter enzyme is indirectly included in the ferricyanide assay.

Mixing experiments with sonicates of fibroblasts from the patient and the control subjects, performed essentially as described by Farrell et al. (12) for liver homogenates, did not demonstrate

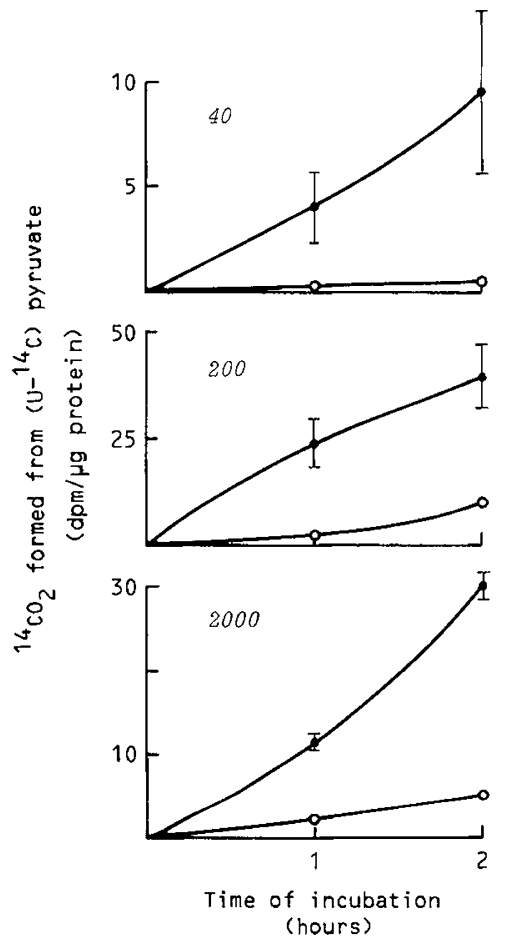

Fig. 1. Formation of ${ }^{14} \mathrm{CO}_{2}$ from $\left[U-{ }^{14} \mathrm{C}\right]$ pyruvate by cultured fibroblasts from the patient $(\mathrm{O}-\mathrm{O})$ and three normal control subjects (- - $)$. The radioactive pyruvate was added to washed fibroblasts at time zero to a final concentration of 40,200 , and 2,000 $\mu \mathrm{mol} /$ liter (about $0.2,0.5$, and 0.8 $\mu \mathrm{Ci} /$ flask) in $2 \mathrm{ml}$ Hanks balanced salt solution ( $\mathrm{pH} 7.2,25^{\circ}$ ). The incubation temperature was $37^{\circ}$. All strains had been subcultured eight times. The flasks $(30 \mathrm{ml})$ contained about $0.4 \mathrm{mg}$ fibroblast protein. Each result given represents the average of three parallel incubations. The results obtained with the three control strains are presented as means \pm SD.

Table 2. Enzyme activities in sonicated fibroblasts from patient and three normal control subjects ${ }^{1}$

\begin{tabular}{lcc}
\hline \multicolumn{1}{c}{ Enzyme } & $\begin{array}{c}\text { Catalytic concentration, } \\
\text { nmol } \times \min ^{-1} \times \mathrm{g} \\
\text { protein }\end{array}$ \\
\cline { 2 - 3 } & Controls & Patient \\
\hline Citrate synthase $\times 10^{-3}$ & $55.9 \pm 8.8$ & 61.7 \\
Pyruvate dehydrogenase complex & $166 \pm 36$ & 13 \\
Pyruvate dehydrogenase (1 unit) & $50.3 \pm 2.6$ & 2.0 \\
\hline
\end{tabular}

${ }^{1}$ The three enzymes were assayed as described in detail in the text. The results represent the mean of two experiments.

${ }^{2}$ Mean \pm SD of three controls. 
soluble inhibitors of the enzyme (Table 3 ). Thus, the activity of pyruvate dehydrogenase (first unit) of the mixture was found to be close to the activity expected from calculations. These results also make it less likely that the reduced activity of the dehydrogenase (Table 2) was secondary to a deficiency of the activating phosphatase. In the mixing experiments the activity of the complete complex was $26 \%$ higher than expected (Table 3 ). This is in accordance with findings of Farrell et al. (12) using liver homogenate; however, the fibroblast results were less pronounced. This indicates that an intercomplex exchange of components of the pyruvate dehydrogenase complex of fibroblasts takes place, and that the defected first unit is normally present in excess.

Fibroblasts cultured from skin biopsies of both parents showed a rate of ${ }^{14} \mathrm{CO}_{2}$ formation with $\left[1-{ }^{14} \mathrm{C}\right]$ pyruvate lower than the rate of normal fibroblasts (Fig. 2), compatible with the parents to be heterozygous carriers. With glucose as substrate these fibroblasts showed simultaneously a slightly increased rate of lactate formation as compared with normal fibroblasts, being 38 (mother), 40 (father), and $32 \pm 3$ (mean $\pm \mathrm{SD}$ of three normal control subjects) $\mu \mathrm{mol} \cdot \mathrm{min}^{-1} \cdot \mathrm{g}$ protein ${ }^{-1}$ over an incubation period of $1.5 \mathrm{hr}$. However, in two experiments with cell-free sonicates, we found the activity of the pyruvate dehydrogenase complex as well as the first unit of the complex to be markedly increased in fibroblasts from both the parents. These unexpected findings must be verified by further studies (46).

\section{DISCUSSION}

The present report concerns an infant who developed metabolic acidosis, hyperlactatemia, and lactaturia during the first days of life. No obvious underlying disease leading to secondary lactic acidosis was discovered. This together with the comparatively high levels of alanine found in serum and urine (33), the normal lactate to pyruvate ratio in urine (25), and the moderate increase in 2-hydroxybutyrate in urine (27) indicated that this child had a congenital lactic acidosis.

A definite classification of a patient with congenital lactic acidosis, which may have both prognostic and therapeutic implications of great value, requires the demonstration of the underlying defect. This has been evident only in a small group of the patients reported in the literature (see introductory section). In addition to the four enzyme defects shown previously to be present in congenital lactic acidosis, various other errors have been suggested on the basis of indirect evidence. Thus, possible errors in the citric acid cycle $(13,17,21)$ and in the electron transport chain (30) as well as in the glyconeogenesis (34) have been discussed. An increased glycolysis has been proposed several times based on, e.g., the finding of an increased glucose metabolism of blood cells (11, 38 ). The latter could easily be a secondary phenomenon, analogous to the increased lactate formation from glucose found in the fibroblasts from our patient (8).

A localization of the enzyme deficiency based on clinical findings and routinely performed biochemical examinations is as yet not possible. However, it seems as if valuable information with relation to the pathogenesis should be possible merely by examining carefully the amino acids and organic acids in urine and serum. The relationship between glucose/pyruvate metabolism and the directly linked main amino acids is shown in Figure 3. Secondary to the increased pyruvate, we found high values of alanine and serine, less marked elevation of glycine, and threonine in serum and urine. High levels of the glyconeogenetic amino acids argue against hypoxia as a primary cause of the lactic acidosis (33).

If a defect is present in the citric acid cycle or closely linked to this cycle, a derangement of the relative concentrations of the citric acid intermediates and the directly involved amino acids would be expected (Fig. 3). Some of the reported patients with congenital lactic acidosis have shown increased excretion of $\alpha$-oxoglutarate both with and without an extra load of glutamate $(13,17,21,32)$. This has been interpreted as suggesting a block in the citric acid cycle. Semiquantitative analyses of urine from our patient showed low amounts of citrate, isocitrate, and cis-aconitate (the first
Table 3. Activity of pyruvate dehydrogenase (I unit) and complete complex in $50 \%$ mixture of sonicated fibroblasts from patient and control subject ${ }^{1}$

\begin{tabular}{ccccc}
\hline & \multicolumn{4}{c}{$\begin{array}{c}\text { Catalytic concentration, } \\
\mathrm{nmol} \times \mathrm{min}^{-1} \times \mathrm{g}^{2} \text { protein }\end{array}$} \\
\cline { 2 - 5 } Enzyme & $\begin{array}{c}\text { Control } \\
(100)\end{array}$ & $\begin{array}{c}\text { Patient } \\
(100)\end{array}$ & $\begin{array}{c}\text { Control/ } \\
\text { patient } \\
(50 / 50)\end{array}$ & $\begin{array}{c}\text { Calcu- } \\
\text { lated } \\
(50 / 50)\end{array}$ \\
\hline $\begin{array}{c}\text { Pyruvate dehydrogenase } \\
\text { complex }\end{array}$ & 130 & 12.6 & 89.5 & 71.1 \\
$\begin{array}{c}\text { Pyruvate dehydrogenase } \\
\text { (1 unit) }\end{array}$ & 49.8 & 2.0 & 26.4 & 25.9 \\
\hline
\end{tabular}

${ }^{1}$ The preincubation period was increased from that regularly used, from $3 \mathrm{~min}$ to $10 \mathrm{~min}$. The results represent the mean of two experiments.

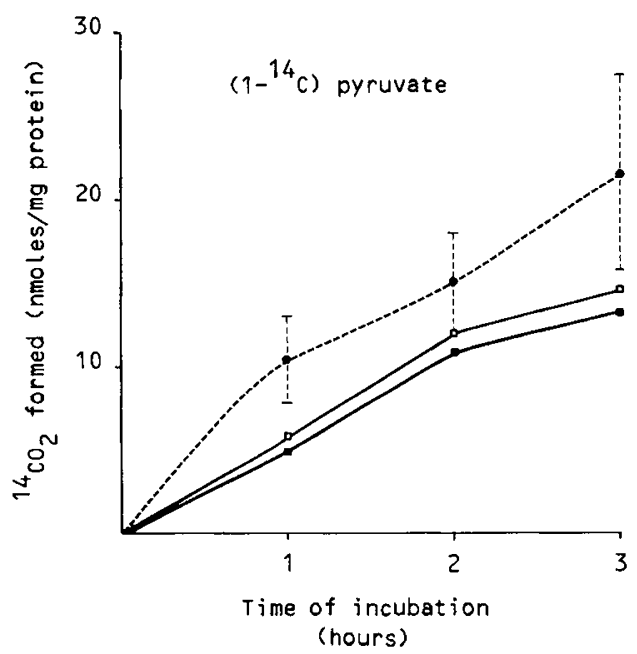

Fig. 2. Formation of ${ }^{14} \mathrm{CO}_{2}$ from $\left[1-{ }^{14} \mathrm{C}\right]$ pyruvate by cultured fibroblasts from the mother $(\square--\square)$, the father ( $\square-\square)$, and six normal control subjects $(\mathrm{O}-\mathrm{O})$. The final $\left[1{ }^{14} \mathrm{C}\right]$ pyruvate concentration was 200 $\mu \mathrm{mol} /$ liter $(0.5 \mu \mathrm{Ci} /$ flask $)$. All strains had been subcultured seven times. The experimental conditions were otherwise as stated in Figure 1.

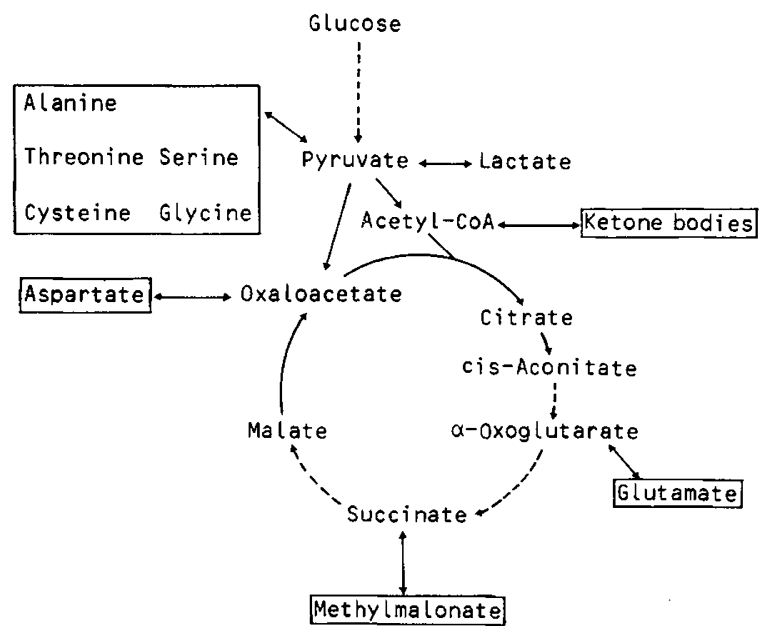

Fig. 3. The oxidative pathway for lactate-pyruvate and its relationship to the closest linked amino acids.

intermediates of citric acid cycle), and levels of $\alpha$-oxoglutarate, succinate, and malate (intermediates in the middle of the cycle) that were not elevated. More likely, $\alpha$-oxoglutarate was decreased as indicated by the low serum and urine levels of glutamate/glutamine. The increased aspartate in serum and urine, on the other hand, indicated a corresponding increase of oxaloacetate, which is 
the last intermediate of the citric acid cycle. This particular amino acid and organic acid patterns pointed in direction of an in vivo block in the oxidative pathway of pyruvate at the level of or above citrate synthase (Fig. 3).

Metabolic studies with intact fibroblasts verified a defect in the oxidation of pyruvate. Enzyme studies in cell-free preparations, in which the regulation systems of enzymes are destroyed, localized the defect to the pyruvate dehydrogenase complex, more specifically to the first of the three enzyme units of the complex. This first unit, pyruvate dehydrogenase, occurs in a phosphorylated inactive or a dephosphorylated active form, the state of which is dependent upon two other enzymes, an inactivating kinase and an activating phosphatase. The ferricyanide assay used to determine the pyruvate dehydrogenase indirectly includes both of these regulatory enzymes. However, the mixing experiments presented in Table 3 seem to exclude the presence of abnormal activities of these enzymes. Previously, at least two different enzyme defects localized to this complex have been demonstrated in congenital lactic acidosis; one in the pyruvate dehydrogenase similar to the present finding $(5,6,12)$, the other in either the dihydrolipoyl transacetylase or in the dihydrolipoyl dehydrogenase (7).

Unfortunately the child in our study died before the exact diagnosis was reached. A child with this error should, on theoretical basis, be treated with a diet comparatively rich in fat and correspondingly low in proteins and particularly in carbohydrates. In addition, thiamine and possibly also lipoic acid and biotin ought to be given.

On autopsy, nonobstructive hydrocephalus with grossly reduced gray and white substance was demonstrated. The histologic alterations were nonspecific, and clear-cut signs of Leigh's encephalomyelopathy were absent. Pathologic changes in the brain are regularly found in congenital lactic acidosis (22). One may speculate whether or not this involves the central role of glucose in the energy production of brain tissue, knowing that the underlying metabolic defect giving rise to lactic acidemia has to be localized some place in the pathway of carbohydrate metabolism. It is important in this regard that there is no net output of lactate from the brain (16). Indeed, the pyruvate formed has to be oxidized via pyruvate dehydrogenase (10).

\section{SUMMARY}

An infant who died at 3 weeks of age from primary lactic acidosis is described. Marked derangements were found in the normal concentration patterns of amino acids and organic acids in serum and urine, compatible with the presence of an in vivo defect in the oxidation of pyruvate. The importance of these patterns as a guideline to the underlying metabolic defect is discussed. Subsequent studies with fibroblasts demonstrated a severe deficiency of the pyruvate dehydrogenase, i.e., the first unit of the pyruvate dehydrogenase complex.

\section{REFERENCES AND NOTES}

1. Antener, I.: Biochemische Untersuchungen bei erblichen Aminosäuerstoffwechselstörungen in der Pädiatrie. Z. Klin. Chem. Klin. Biochem., 7: 427 (1969).

2. Armstrong, M. D., and Stave, U.: A study of plasma free amino acid leveis. II. Normal values for children and adults. Metabolism, 22: 561 (1973)

3. Baker, L., and Winegrad, A. I.: Fasting hypoglycaemia and metabolic acidosis associated with deficiency of hepatic fructose-1,6-diphosphatase activity. Lancet, ii: 13 (1970).

4. Baerlocher, K., Gitzelmann, R., Nüssli, R., and Dumermuth, G.: Infantile lactic acidosis due to hereditary fructose 1,6-diphosphatase deficiency. Helv. Paediat. Acta, 26: 489 (1971).

5. Blass, J. P., Avigan, J., and Uhlendorf, B. W.: A defect in pyruvate decarboxylase in a child with an intermittent movement disorder. J. Clin. Invest., 49: 423 (1970).

6. Blass, J. P., Lonsdale, D., Uhlendorf, B. W., and Hom, E.: Intermittent ataxia with pyruvate-decarboxylase deficiency. The Lancet, $i$ : 1302 (1971).

7. Blass, J. P., Schulman, J. D., Young, D. S., and Hom, E.: An inherited defect affecting the tricarboxylic acid cycle in a patient with congenital lactic acidosis. J. Clin. Invest., 51: 1845 (1972).

8. Borud, O., and Strömme, J. H.: In preparation.

9. Brodehl, J., and Gellissen, K.: Endogenous renal transport of free amino acids in infancy and childhood. Pediatrics, 42: 395 (1968).
10. Cremer, J. E., and Teal, H. M.: The activity of pyruvate dehydrogenase in rat brain during postnatal development. Fed. Eur. Biochem. Soc. Lett. 39: 17, (1974).

11. Erickson, R. J. Familial infantile lactic acidosis. J. Pediat., 66: 1004 (1965).

12. Farrell, D. F., Clark, A. F., Scott, C. R., and Wennberg, R.P.: Absence of pyruvate decarboxylase activity in man: A cause of congenital lactic acidosis. Science, 187: 1082 (1975).

13. Greene, H. L., Schubert, W. K., and Hug, G.: Chronic lactic acidosis in infancy. J. Pediat., 76: $853(1970)$

14. Grover, W. D., Auerbach, V. H., and Patel, M. S.: Biochemical studies and therapy in subacute necrotizing encephalomyelopathy (Leigh's syndrome). J. Pediat., 81: 39 (1972).

15. Hartmann, A. F., Wohltmann, H. J., Purkerson, M. L., and Wesley, M. E.: Lactate metabolism: Studies of a child with serious congenital deviation. $\mathbf{J}$. Pediat., 61: 165 (1962).

16. Hawkins, R. A., Miller, A. L., Nielsen, R. C., and Weech, R. L.: The acute action of ammonia on rat brain metabolism in vivo. Biochem. J., 134: 1001 (1973).

17. Haworth, J. C., Ford, J. D., and Younoszai, M. K.: Familial chronic acidosis due to an error in lactate and pyruvate metabolism. Can. Med. Ass. J., 97: 773 (1967).

18. Hommes, F. A.: Personal communication.

19. Hommes, F. A., Polman, H. A., and Reering, J. D.: Leigh's encephalomyelopathy: An inborn error of gluconeogenesis. Arch. Dis. Childhood, 43: 423 (1968).

20. Hultberg, B., and Ockerman, P. A.: Urinary excretion of amino acids in juvenile amaurotic idiocy. Metabolism, 2i: 231 (1972).

21. Israels, S., Haworth, J. C., Gourley, B., and Ford, J. D.: Chronic acidosis due to an error in lactate and pyruvate metabolism: Report of two cases. Pediatrics, 34: 346 (1964).

22. Lie, S. O., Löken, A. C., Strömme, J. H., and Aagenaes, Ö.: Fatal congenital lactic acidosis in two siblings. I. Clinical and pathological findings. Acta Paediat. Scand., 60: 129 (1971).

23. Lowry, O. H., Rosebrough, N. J., Farr, A. L., and Randall, R. J.: Protein measurement with the Folin phenol reagent. J. Biol. Chem., 193: 265 (1951).

24. Nordmann, J., and Nordmann, R.: Organic acids. In: I. Smith: Chromatographic and Electrophoretic Techniques, Vol. i, p. 342 (W. Heinemann, Medical Books, London, 1969).

25. Oliva, P. B.: Lactic acidosis. Amer. J. Med., 48: 209 (1970).

26. Pagliara, A. S., Karl, J. E., Keating, J. P., Brown, B., and Kipnis, D. M.: Hepatic fructose-1,6-diphosphatase deficiency. J. Clin. Invest., 51: 2115 (1972).

27. Pettersen, J. E., Landaas, S., and Eldjarn, L.: The occurrence of 2-hydroxybutyric acid in urine from patients with lactic acidosis. Clin. Chim. Acta. 48: 213 (1973).

28. Przyrembel, H., Leupold, D., Tosberg, P., and Bremer, H. J.: Amino acid excretion of premature infants receiving different amounts of protein. Clin. Chim. Acta, 49: 27 (1973).

29. Reed, L. J., and Willms, C. R.: Pyruvate decarboxylase. Methods Enzymol., 9: 258 (1966).

30. Senior, B., and Jungas, R. L.: A disorder resulting from an enzymatic defect of the respiratory chain. Pediat. Res., 8: 438 (1974).

31. Schärer, K.: Congenital lactic acidosis. In: J. Stern and C. Toothill: Organic acidurias. Proceedings of the Ninth Symposium of the Society for the Study of Inborn Errors of Metabolism, p. 46 (Churchill, Livingstone, Edinburgh, 1972).

32. Schärer, K., Marty, A., and Mühlethaler, J. P.: Chronic congenital lactic acidosis: A fatal case with hyperphosphatemia and hyperlipemia. Helv. Paediat. Acta, 23: 107 (1968).

33. Scriver, C. R., and Rosenberg, L. E.: Amino Acid Metabolism and Its Disorders, p. 440 (Saunders Company, Philadelphia, 1973).

34. Skrede, S., Strömme, J. H., Stokke, O., Lie, S. O., and Eldjarn, L.: Fatal congenital lactic acidosis in two siblings. II. Biochemical studies in vivo and in vitro. Acta Paediat. Scand., 60: 138 (1971).

35. Sitzman, F. E.: Normalwerttabellen für Neugeborene, Säuglinge und Ältere Kinder. Pädiat. Prax., S: 13 (1966).

36. Spackman, D. H., Stein, W. H., and Moore, S.: Automatic recording apparatus for use in the chromatography of amino acids. Anal. Chem., 30: 1190 (1958)

37. Tada, K., Sugita, K., Fujitani, K., Uesakai, T., Takada, G., and Omura, K.: Hyperalaninemia with pyruvicemia in a patient suggestive of Leigh's encephalomyelopathy. Tohoku J. Exp. Med., 109: 13 (1973).

38. Worsley, H. E., Brookfield, R. W., Elwood, J. S., Noble, R. L., and Taylor, W. H.: Lactic acidosis with necrotizing encephalopathy in two sibs. Arch. Dis. Childhood, 40: 492 (1965)

39. Wright, J. A., and Sanwal, B. D.: Regulatory mechanisms involving nicotinamide adenine nucleotides as allosteric effectors. J. Biol. Chem., 246: 1689 (1971).

40. The autopsy was kindly performed by Professor H. Stalsberg, Institute of Medical Biology, University of Tromsö, Tromsö, Norway.

41. Amersham, England

42. Grand Island, New York.

43. Mannheim, Germany.

44. St. Louis, Mo.

45. InstaGel, Packard

46. Further studies failed to verify these data (note added in proof).

47. We wish to thank Oddvar Gamst for excellent technical assistance.

48. This study was presented in part at the Ninth International Congress in Clinical Chemistry, July 1975, Toronto, Canada.

49. Requests for reprints should be addressed to: J. H. Strömme, M.D., Institute of Medical Biology, University of Tromsö, N-9000 Tromsö. (Norway).

50. Accepted for publication September 3, 1975. 